\title{
PENINGKATAN PRODUKTIFITAS DAN PEMBEKALAN MITIGASI RISIKO KEGIATAN BANK SAMPAH DI ERA PANDEMI COVID-19
}

\author{
M. Hasan Abdullah ${ }^{1}$, Astria Hindratmo², Yudy Christiono ${ }^{3}$ \\ ${ }^{1}$ Teknik Industri Universitas Wijaya Putra \\ ${ }^{2}$ Teknik Industri Universitas Wijaya Putra \\ ${ }^{3}$ Teknik Industri Universitas Wijaya Putra
}

mhasanabdullah@uwp.ac.id, astriahindratmo@uwp.ac.id, yudychristiono@gmail.com

\begin{abstract}
Abstrak
Pandemi Covid-19 hampir berdampak pada seluruh kegiatan masyarakat. Produktifitas menjadi bagian yang sangat terpuruk akibat adanya pembatasan kegiatan sosial, tak terkecuali pada kegiatan Bank Sampah. Bank Infaq Sampah Al-Muhajirin (BISA) yang berlokasi di tengah wilayah RW 09 Manukan Kulon dan RW 01 Banjarsugihan Kecamatan Tandes Kota Surabaya merupakan salah satu yang terdampak. Sampah plastik merupakan sampah yang mempunyai volume terbesar. Bank sampah hanya bisa mengolah sampah plastik botol dan gelas dalam kondisi bersih sebesar $20 \%$ saja, $80 \%$ sampah tidak terproses dengan baik. Hal ini disebabkan karena kurangnya petugas dan peralatan pendukung. Selain permasalahan produktifitas, kesadaran tentang kesehatan dan keselamatan kerja masih belum diperhatikan. Tujuan Program Pemberdayaan Masyarakat ini adalah untuk meningkatkan produktifitas serta membangun kesadaran pentingnya kesehatan dan keselamatan kerja di bank sampah terutama di masa Pandemi Covid-19 saat ini. Metode penyuluhan dan pelatihan K3 diberikan pada mitra agar tumbuh kesadaran tentang bahaya yang ada di lingkungan sekitar serta bagaimana melakukan mitigasi. Mitra juga diberikan pendampingan dalam memilah sampah plastiK dan mendesain mesin pengolah sampah plastik yang sesuai dengan kebutuhan. Penggunaan masker, sarung tangan dan pemberian disinfektan pada tempat kerja menjadi protokol wajib dalam aktifitas bank sampah.
\end{abstract}

Kata Kunci : bank sampah, kesehatan kerja, pengolah plastik

\section{PENDAHULUAN}

Pandemi Covid-19 hampir berdampak pada seluruh kegiatan masyarakat. Produktifitas menjadi bagian yang sangat terpuruk akibat adanya pembatasan kegiatan sosial, tak terkecuali pada kegiatan Bank Sampah. Bank Infaq Sampah AlMuhajirin (BISA) yang berlokasi di tengah wilayah RW 09 Manukan Kulon dan RW 01 Banjarsugihan Kecamatan Tandes Kota Surabaya merupakan salah satu yang terdampak. Mitra merupakan sebuah bank sampah yang bergerak di bidang pengelolaan sampah anorganik. Sampah dari warga dikirim ke bank sampah, kemudian sampah tersebut dipilah dan dibersihkan sesuai dengan jenisnya (Hadiyanto, 2011). Bank sampah ini sudah mulai berkatifitas sejak tahun 2017.

Dari data diketahui bahwa untuk jenis sampah plastik membutuhkan ruang penyimpanan pada gudang sebesar 50\% dari tempat yang dimiliki bank sampah. Sampah plastik terdiri dari semua jenis plastik yang mempunyai bentuk (volume) seperti 
bekas botol dan gelas minuman, tempat shampoo, timba, dan semua gerabah dari plastik. Untuk jenis plastik lembaran terdiri dari kantong plastik (kresek), plastik pembungkus makanan dan jenis plastik pembungkus lainnya. Sampah-sampah plastik tersebut dipilah dan disimpan sesuai jenisnya (Setiobudi, 2018).

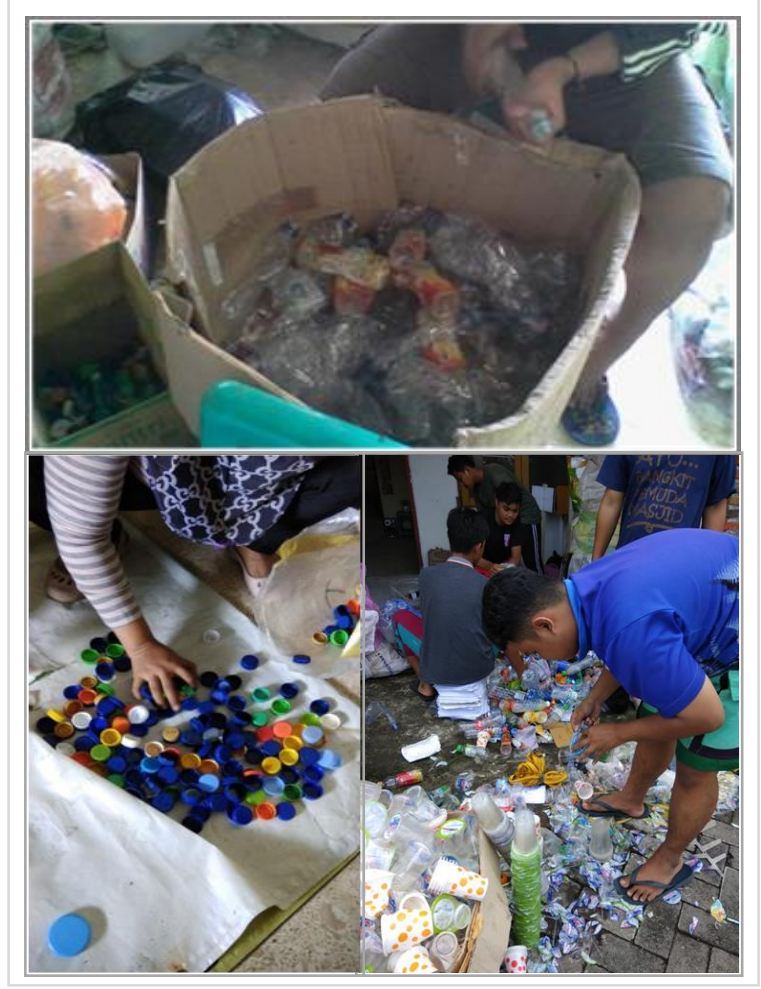

Gambar 1. Proses pilah dan pembersihan sampah plastik

Selain mempunyai volume yang cukup besar, sampah plastik ini memerlukan proses pemilahan yang lebih rumit dibandingkan dengan jenis sampah yang lain (Yetri \& dkk, 2016). Hasil observasi diperoleh bahwa hasil produksi memilah sampah plastik rata-rata sebesar $2,5 \mathrm{~kg} / \mathrm{jam}$. Sampah plastik dipilah sesuai jenisnya sebagaimana pada Gambar 1. Botol plastik dipisahkan dari tutupnya kemudian dibuang sisa minuman yang ada. Botol yang sudah kosong dibersihkan dari label plastik yang masih menempel dan dikremas / ditekan dengan tangan supaya volume lebih kecil, kemudian dimasukkan karung penyimpanan. Untuk sampah gelas plastik, dilakukan pembersihan tutupnya kemudian dibuang sisa air sampai bersih. Hal ini membutuhkan banyak waktu dan sangat melelahkan bagi petugas bank sampah.

Selain permasalahan produktifitas, kesadaran tentang kesehatan dan keselamatan kerja masih belum diperhatikan. Petugas tidak memakai masker atau sarung tangan dalam bekerja. Padahal di tempat tersebut banyak sampah anorganik yang masih terdapat sisa makanan atau minuman serta zat kimia berbahaya yang berpotensi menularkan bibit penyakit dan membahayakan kesehatan.

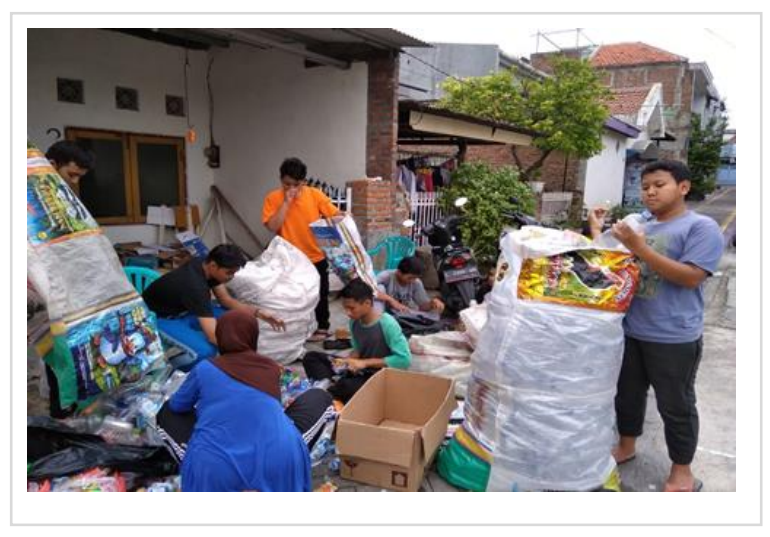

Gambar 2. Kondisi Kerja di Bank Sampah. Sebelum pandemi

Sisa makanan dan minuman yang sudah membusuk sering dijumpai oleh petugas bank sampah. Terdapat juga botol bekas insektisida, pembersih pakaian, toilet serta botol-botol bekas lainnya masih menyimpan sisa atau residu berbahaya. Hal ini perlu dilakukan sosialisasi dan pelatihan tentang bahaya dan cara penanganan agar petugas tetap terjaga kesehatan dan keselamatannya.

Dari permasalahan yang dikemukakan di atas, maka perlu solusi agar produktifitas bank sampah meningkat dan petugas mempunyai kesadaran akan pentingnya kesehatan dan keselamatan kerja. Melalui diskusi Tim pengusul program PPM dengan mitra, maka disepakati beberapa kegiatan yang akan dilakukan.

\section{METODE}

Lingkungan Hidup dan Kenencanaan 
Metode pelaksanaan pada program pengabdian ini didasarkan pada hasil analisis situasi pada mitra dan melibatkan transfer Iptek pada setiap tahapannya. Supaya setiap proses berlangsung dengan baik, maka penyampaian inovasi kepada Mitra ditempuh melalui tahapan penjelasan, diskusi, praktek serta dilakukan tahapan pendampingan (Kusnawati, 2012). Melalui proses-proses tersebut diharapkan inovasi dapat diadopsi secara berkesinambungan, serta target sasaran mempunyai kemampuan untuk melakukan analisis terhadap perkembangan usahanya, serta mampu mengembangkan inovasi yang telah dikuasainya (Dwiyanto, 2011). Secara umum pendekatan untuk membantu Mitra dalam peningkatan produktifitas Bank Sampah ditunjukkan pada Gambar 3 berikut.

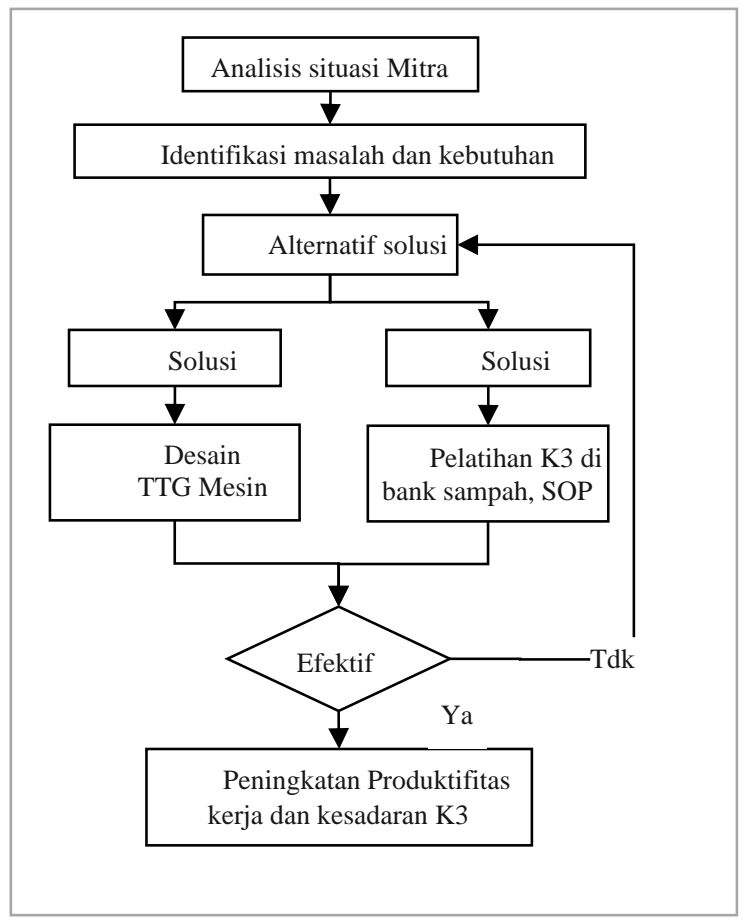

Gambar 3. Diagram metode pelaksanaan pengabdian

Perancangan Teknologi Tepat Guna (TTG) untuk Mitra diawali dengan identifikasi kebutuhan terhadap Mesin pengolah plastik yang akan digunakan. Beberapa atribut dan fungsi alat yang diinginkan oleh Mitra akan dilakukan skala prioritas. Dari atribut tersebut maka akan ditentukan spesifikasi teknis pada perancangan alat. Dari spesifikasi teknis tersebut akan disusun beberapa konsep desain dan estimasi biaya pembuatan. Konsep-konsep yang sudah dibuat kemudian dilakukan diskusi dengan Mitra untuk dilakukan seleksi. Evaluasi dan perbaikan konsep bisa terjadi karena faktor tingkat kesulitan dan biaya pembuatan. Konsep yang sudah terpilih inilah yang akan diaplikasikan pada rancangan Mesin.

\section{HASIL DAN PEMBAHASAN}

\section{Perancangan Alat pengolah plastik}

Kegiatan ini dilakukan untuk merancang alat yang dapat melumat sampah plastik berupa botol, gelas atau yang berbentuk non lembaran. Agar desain sesuai dengan kebutuhan Mitra maka dilakukan diskusi dengan para petugas bank sampah. Dari hasil diskusi diperoleh bahwa rancangan alat tersebut bisa digunakan dengan daya listrik yang rendah dan mudah untuk digunakan (Yetri \& dkk, 2016).

Desain alat minimalis agar mudah untuk dipindahkan. Dilengkapi dengan Motor listrik berdaya rendah dan gearbox sehingga mempunyai kemampuan menghancurkan dengan optimal (Syamsiro, 2016) dan (Nuryati, 2015).

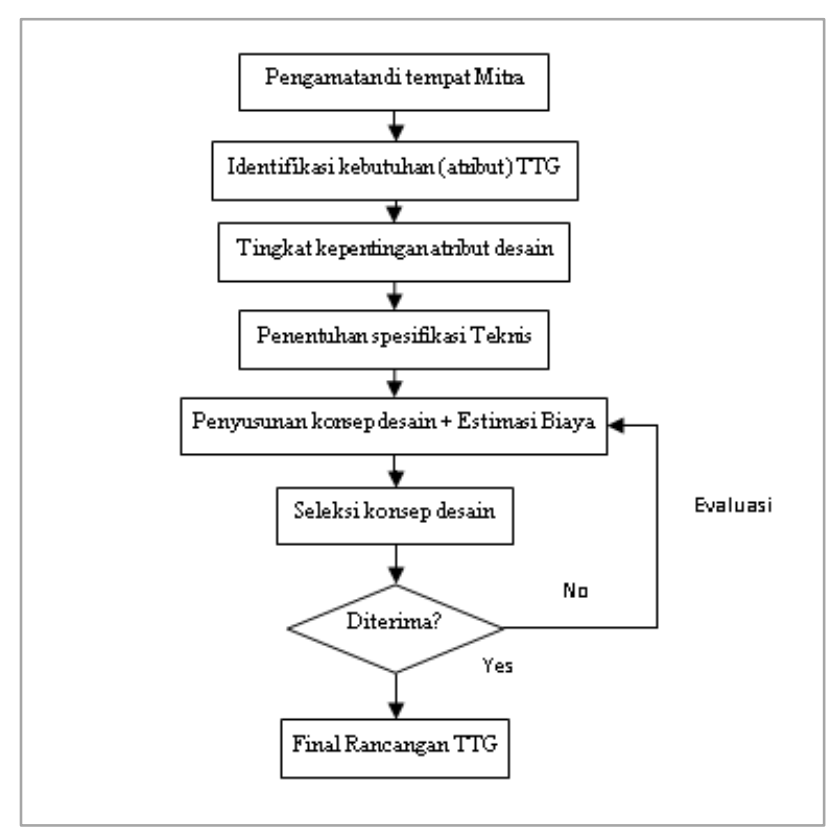

Gambar 4. Diagram proses desain alat

Lingkungan Hidup dan Kenencanaan 
Perancangan Teknologi Tepat Guna (TTG) untuk Mitra diawali dengan identifikasi kebutuhan terhadap Mesin pengolah plastik yang akan digunakan. Beberapa atribut dan fungsi alat yang diinginkan oleh Mitra akan dilakukan skala prioritas. Dari atribut tersebut maka akan ditentukan spesifikasi teknis pada perancangan alat. Dari spesifikasi teknis tersebut akan disusun beberapa konsep desain dan estimasi biaya pembuatan. Konsep-konsep yang sudah dibuat kemudian dilakukan diskusi dengan Mitra untuk dilakukan seleksi. Evaluasi dan perbaikan konsep bisa terjadi karena faktor tingkat kesulitan dan biaya pembuatan. Konsep yang sudah terpilih inilah yang akan diaplikasikan pada rancangan Mesin. Gambar rancangan detail alat seperti pada Gambar 5 berikut.

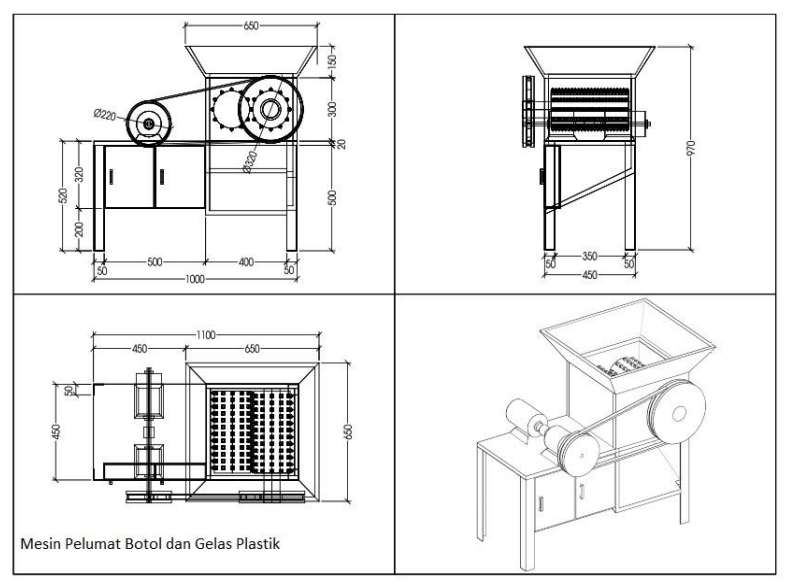

Gambar 5. Detil rancangan alat

Komponen Utama alat terdiri dari, Motor listrik AC 220 V / 50Hz / 1 Phase, Reducer / Gearbox 1:20 Silider bergerigi (fixed dan adjustable), Pulley gearbox, Pulley silinder, V-Belt atau rantai, Body (kerangka) dari besi.

\section{Identifikasi dan Mitigasi Risiko}

Identifikasi risiko dilakukan untuk mengetahui bahaya apa saja yang berpotensi merugikan terhadap kesehatan dan keselamatan petugas di tempat kerja. Dengan demikian dapat dilakukan tindakan pencegahan untuk menghilangkan atau mengurangi dampak dari risiko tersebut. Dari beberapa potensi risiko yang teridentifikasi, petugas bank sampah kemudian diberikan pemahan tentang bagaimana melakukan mitigasi pada risiko-risiko tersebut. Sumber risiko berasal dari barang-barang (sampah) yang terkumpul di bank sampah. Selain itu, adanya pandemi Covid19 juga menjadi prioritas dalam mitigasi risiko. Beberapa risiko yang teridentifikasi antara lain sebagai seperti pada tabel 1 .

Tabel 1. Identifikasi Risiko di Bank Sampah

\begin{tabular}{|c|l|}
\hline No & \multicolumn{1}{|c|}{ Risiko } \\
\hline 1 & $\begin{array}{l}\text { Iritasi kulit pada tangan atau bagian lain pada } \\
\text { anggota tubuh yang terbuka. }\end{array}$ \\
\hline 2 & $\begin{array}{l}\text { Iritasi pada mata. Mata terkena debu, air kotor, } \\
\text { atau benda lain yang membahayakan. }\end{array}$ \\
\hline 3 & $\begin{array}{l}\text { Menghirup debu, bau tidak sedap yang menggangu } \\
\text { pernapasan. }\end{array}$ \\
\hline 4 & $\begin{array}{l}\text { Kaki tertusuk benda tajam atau tertindih barang } \\
\text { berat. }\end{array}$ \\
\hline 5 & $\begin{array}{l}\text { Terpapar Covid-19 dari seseorang sebagai carier } \\
\text { atau dari barang-barang lain yang terkontaminasi } \\
\text { virus. }\end{array}$ \\
\hline
\end{tabular}

Dengan mengetahui jenis dan sumber resiko maka dapat dilakukan tindakan pencegahan yang diperlukan.

\section{Pelatihan dan Penerapan K3 pada Bank Sampah}

Setelah diketahui risiko yang ada, maka petugas bank sampah diberikan pengetahuan bagaimana melakukan pencegahan melalui penggunaan Alat Pelindung Diri (APD). APD minimal yang harus digunakan antara lain Masker, kaca mata, sarung tangan dan sepatu. Petugas dilatih bagaimana menggunakan APD secara tepat sebelum dan setelah dipakai. 


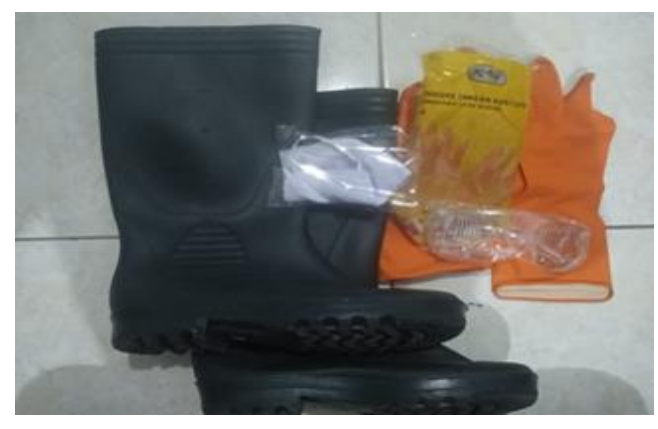

Gambar 6. Alat Pelindung Diri (APD). Sepatu safety, sarung tangan karet, kaca mata pelindung dan masker

Penggunaan APD ini digunakan bagi petugas yang melakukan pekerjaan yang bersentuhan langsung dengan barang-barang bekas atau sampah, khususnya barang yang kotor dan terkontaminasi dengan zat berbahaya seperti oli, sisa makanan dan minuman, sisa pembersih dan lainnya. Area pemilahan dan penyimpanan barang berbahan logam dan kaca juga harus menjadi perhatian petugas. Gambar 7 menunjukkan petugas memakai APD dalam melakukan pekerjaan di bank sampah.

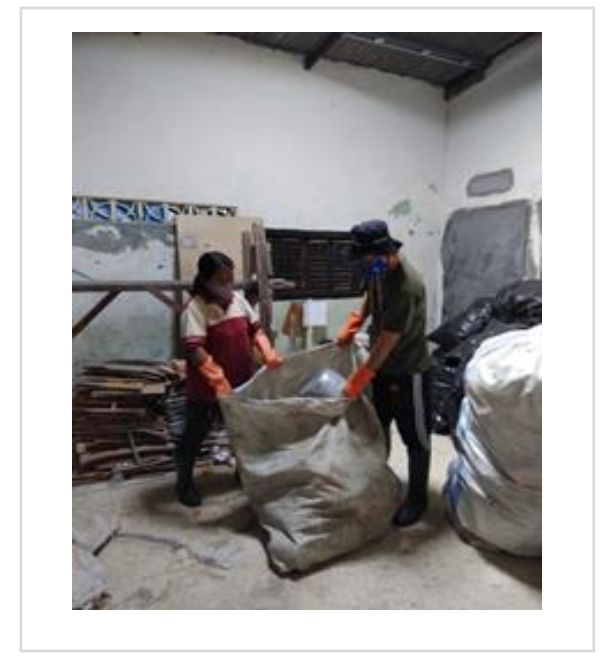

Gambar 7. Aplikasi APD pada Petugas

Untuk petugas bagian administrasi cukup menggunakan APD berupa masker dan sarung tangan kain biasa untuk menghindari sentuhan langsung sebagai protokol kesehatan terhadap Covid-19.

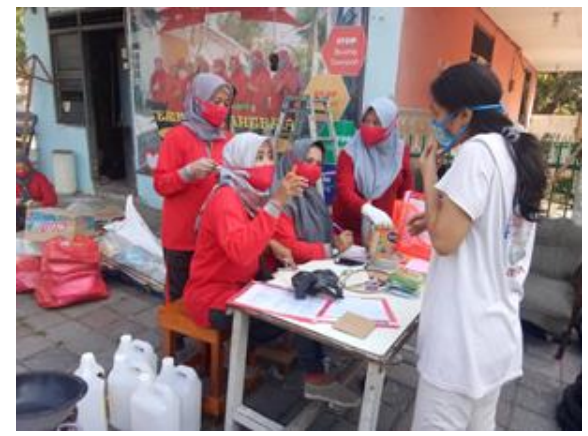

Gambar 8. Aplikasi APD pada Petugas Adminisrasi

Sebelum aktifitas bank sampah dimulai, dilakukan penyemprotan dengan disinfektan. Penyemprotan ini dilakukan sebagai upaya untuk mengurangi atau menghindari penyebaran Virus terutama Covid-19. Bahan desinfektan yang digunakan sesuai dengan yang dianjurkan oleh dinas kesehatan.

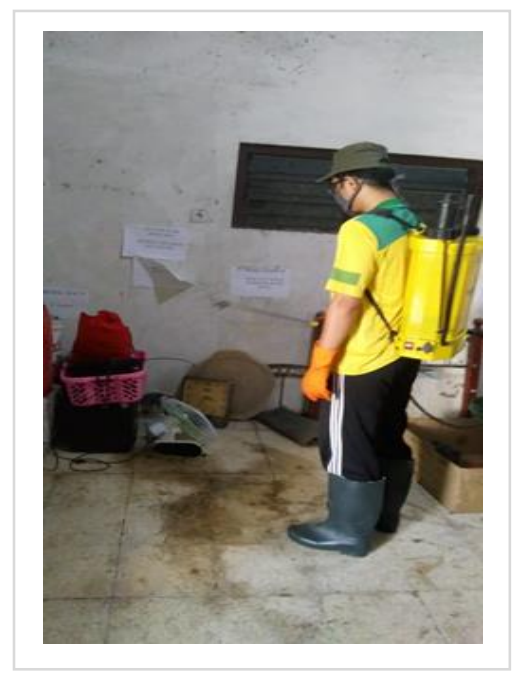

Gambar 9. Penyemprotan disinfektan di area bank sampah oleh petugas

Selama masa pandemi belum berakhir maka kegiatan penyemprotan terus dilakukan secara rutin. Selain penyemprotan, di area bank sampah juga dipasang alat pencuci tangan. Petugas bank dapat melakukan pebersihan tangan sebelum dan setelah melakukan aktifitas pemilahan sampah.

$$
\text { Lingkungan Hidup dan Kenencanaan }
$$


Dengan adanya pelatihan dan pendampingan selama program pengabdian ini, masyarakat terutama para petugas bank sampah akan lebih peduli terhadap kesehatan dan membiasakan diri untuk menjalankan protokol kesehatan dan menggunakan APD sesuai kebutuhan. Petugas bank sampah juga sudah memiliki desain alat pelumat plastik yang akan dibuat. Dengan adanya alat ini, nantinya dapat menyelesaikan proses pemilahan dan pembersihan sampah plastik terutama botol dan gelas secara efisien. Pada program ini alat hanya selesai pada tahap perancangan detil alat. Pembuatan alat akan direalisasikan pada program pengabdian selanjutnya. Tabel 2 berikut merupakan rangkuman kegiatan dan hasil yang dicapai pada program pengabdian.

Tabel 2. Kegiatan dan hasil yang dicapai

\begin{tabular}{|c|c|c|}
\hline Kegiatan & Target & Hasil \\
\hline $\begin{array}{l}\text { Penyuluhan } \\
\text { Mitigasi } \\
\text { Risiko }\end{array}$ & $\begin{array}{l}\text { Mitra/Nasabah } \\
\text { memahami jenis- } \\
\text { jenis bahaya } \\
\text { yang ada pada } \\
\text { aktifitas bank } \\
\text { sampah }\end{array}$ & $\begin{array}{l}\text { Mitra mempunyai } \\
\text { kesadaran dan } \\
\text { berupaya untuk } \\
\text { berhati-hati dengan } \\
\text { menggunakan APD }\end{array}$ \\
\hline $\begin{array}{l}\text { Pelatihan } \\
\text { penggunaan } \\
\text { APD }\end{array}$ & $\begin{array}{l}\text { Mitra memahami } \\
\text { fungsi APD dan } \\
\text { memiliki } \\
\text { ketrampilan } \\
\text { dalam } \\
\text { penggunaannya }\end{array}$ & $\begin{array}{l}\text { Mitra dapat } \\
\text { menggunakan APD } \\
\text { dengan benar dan } \\
\text { terbiasa untuk } \\
\text { menggunakannya }\end{array}$ \\
\hline $\begin{array}{l}\text { Pendampingan } \\
\text { perancangan } \\
\text { alat }\end{array}$ & $\begin{array}{l}\text { Mitra } \\
\text { mempunyai } \\
\text { rancangan alat } \\
\text { yang siap untuk } \\
\text { diproduksi dan } \\
\text { digunakan }\end{array}$ & $\begin{array}{l}\text { Rancangan alat } \\
\text { pelumat plastik }\end{array}$ \\
\hline
\end{tabular}

\section{KESIMPULAN}

Adanya progam pengabdian ini masyarakat terutama para petugas bank sampah mulai tumbuh semangat dan kesadaran untuk memulai aktifitas bank sampah di era new normal. Petugas tidak merasa khawatir setelah mengetahui sumber-sumber risiko dan mengetahui bagaimana cara melakukan pengendaliannya. Produktifitas mulai meningkat setelah beberapa bulan bank sampah tidak beroperasi semenjak masa pandemic covid-19. Pendampingan dilakukan terkait bagaimana merancang alat yang dapat membantu meningkatkan produktifitas bank sampah. Rancanga detil alat sudah selesai, namun realisasi alat masih terkendala dengan pengadaan barang atau spare part yang masih terkendala dengan adanya pandemi. Pada pengabdian selanjutnya akan dilakukan pendampingan pada pembuatan alat dan evalusi terhadap kinerja alat.

\section{UCAPAN TERIMAKASIH}

Terima kasih kami ucapkan kepada Lembaga Penelitian dan Pengabdian Masyarakat (LPPM) dan Fakultas Teknik Universitas Wijaya Putra atas kerjasama dalam penelitian ini.

\section{REFERENSI}

Dwiyanto, B. (2011). Metode Penigkatan Partisipasi masyarakat dan Penguatan Sinergi dan Pengelolaan Sampah Perkotaan. Jurnal Ekonomi Pembangunan, 2.

Hadiyanto, d. (2011). Pengelolaan Sampah Rumah Tangga di kecamatan Daha Selatan. Jurnal Ilmu Lingkungan, vol 9 no 1.

Kusnawati, d. (2012). Pemberdayaan Masyarakat Pengelolaan Sampah di Dusun Mrican Sleman. Jurnal Health and Sport, Vol 5. No. 3.

Nuryati, d. (2015). Rekayas Mesin Penghancur Plastik Knock Down Guna Peningkatan Pengelolaan Limbah Plastik melalui Manajemen Usaha SMART System. Seminar Nasional Universitas PGRI Yogyakarta. Yogyakarta: Universitas PGRI Yogyakarta.

Setiobudi, D. (2018). Peningkatan Nilai Produk pada Kelompok Usaha Kecil Pengepul Barang Bekas di Kecamatan Ambulu dan Kecamatan Jenggawah Kabupaten Jember. Jurnal ROTOR, Vol. 11 No. 1.

Syamsiro, M. (2016). Rancang Bangun Mesin Pencacah Plastik Sebagai Bahan Baku Mesin Pirolisis Skala Komunal. Jurnal Mekanika dan Sistem Termal, 43-48.

Tanjung, H., \& Sutopo, A. (2017). Pengembangan Kelompok Usaha Botot Melalui Pengelolaan Sampah Perkotaan di Kabupaten 
Deliserdang. Seminar Pengabdian Masyarakat. Medan: Universitas Medan.
Yetri, Y., \& dkk. (2016). Rancang Bangun Mesin Pencacah dan Limbah Plastik. Seminar Nasional Pengabdian Masyarakat. 